\section{Mortality in Pond-Cultured Shrimp Penaeus monodon in the Philippines Associated with Vibrio harveyi and White Spot Syndrome Virus}

\author{
Leobert D. de la Peña ${ }^{1 *}$, Celia R. Lavilla-Pitogo', \\ Atsushi Namikoshi' ${ }^{2}$, Toyohiko Nishizawa ${ }^{3}$, \\ Yasuo Inui ${ }^{1}$ and Kiyokuni Muroga ${ }^{2}$ \\ ${ }^{1}$ Fish Health Section, SEAFDEC Aquaculture Department, \\ Tigbauan, Iloilo, Philippines \\ ${ }^{2}$ Graduate School of Biosphere Sciences, Hiroshima \\ University, Higashi-Hiroshima 739-8528, Japan \\ ${ }^{3}$ Graduate School of Fisheries Sciences, Hokkaido Univer- \\ sity, Hakodate, Hokkaido 041-8611, Japan
}

(Received October 4, 2002) and Americas. Although previous efforts ${ }^{3)}$ reported the absence of White spot syndrome virus (WSSV) from cultured or wild $P$. monodon in the Philippines, the disease has recently been confirmed to be present in the country ${ }^{4)}$.

During the first quarter of 1999 , mortalities were observed in shrimp farms in various provinces in the Philippines such as Bohol in the Visayas, Misamis Occidental, Lanao del Norte and Zamboanga del Sur in Mindanao. In this paper, we report the dual infection with the luminescent Vibrio and WSSV in cultured $P$. monodon in the Philippines.

\section{Materials and Methods}

Sampling of diseased shrimp: During the first quarter of 1999 , high mortality rate was experienced in one of the shrimp farms in Bohol. The post larvae were purchased from a private hatchery without screening of WSSV. The farm was practicing intensive culture system with a stocking density of $25 \mathrm{shrimp} / \mathrm{m}^{2}$. Initial signs observed at 30 to 89 days of culture, depending on the pond, was a sudden drop in feed consumption. Shrimp were observed to stay near the edge of the ponds and some emitted greenish light during the night.

Twenty weak shrimp swimming near the edge of two infected ponds with an average body weight (ABW) of $0.4 \mathrm{~g}$ and $14 \mathrm{~g}$ were collected and immediately processed on site for bacterial isolation. Bacteria were isolated from the hepatopancreas and lymphoid organs while the gills and epidermis of the same shrimp sampled for bacterial analysis were fixed in $95 \%$ ethanol for DNA extraction.

In the 3 provinces of Mindanao, 7 affected farms were practicing extensive culture system with a stocking density of 3-5 shrimp $/ \mathrm{m}^{2}$. High mortality and slow growth rates were also observed in the affected farms. Three to 5 weak shrimp from each farm with ABW of $5 \mathrm{~g}$ to $10 \mathrm{~g}$ were collected and processed as above.

Bacteriological tests: Bacteria were isolated from weak shrimp by inoculating samples on Nutrient Agar (NA: BBL) supplemented with $1.5 \% \mathrm{NaCl}$ and Thiosulphate Citrate Bile Salt Sucrose Agar (TCBS: BBL). After $18-24 \mathrm{~h}$ incubation at room temperature $\left(28^{\circ} \mathrm{C}\right)$, pure colonies were selected, purified and maintained frozen at $-80^{\circ} \mathrm{C}$ in Nutrient Broth (NB: BBL) supplemented with $1.5 \% \mathrm{NaCl}$ and $10 \%$ glycerol. Morphological, physiological and biochemical characterization tests and identification were conducted on these isolates as before $^{2)}$. The representative isolates were also subjected to slide agglutination test using rabbit antiserum raised against $V$. harveyi $(\mathrm{PN}-9801)$ isolated in our previous study').

Histopathological tests: Ten shrimp samples from

\footnotetext{
* Corresponding author

E-mail: leobertd@aqd.seafdec.org.ph
} 
each pond in a farm in Bohol and 5 from each farm in Mindanao were preserved in Davidson's fixative. Hepatopancreas was removed and processed routinely and stained with hematoxylin and eosin.

Detection of WSSV by PCR: DNA was extracted from the gills and epidermis taken from 30 shrimp samples (15 shrimp each from Bohol and Mindanao) following the method described by Nonaka et al. (1998) $)^{5}$ with slight modification. The tissues from 5 shrimp were pooled as 1 sample. The DNA samples were submitted to onestep and nested PCR tests using the WSSV-specific primer pairs designed by Kimura et al. (1996) ${ }^{6)}$.

\section{Results}

Bacterial isolation and identification: Pure luminous bacterial colonies were isolated from the hepatopancreas and lymphoid organs of all the shrimps tested. The presumptive Vibrio count on TCBS was $10^{5} \mathrm{cfu} /$ hepatopancreas and both the total plate and luminous bacterial counts on NA exceeded $10^{6} \mathrm{cfu} /$ hepatopancreas. Ten representative luminous bacterial isolates from the hepatopancreas were examined for their morphological, physiological, and biochemical characteristics. Results of detailed characterization tests led to the identification of these isolates to $V$. harveyi as previously reported ${ }^{2)}$. The identity of representative isolates was also confirmed by slide agglutination test to be of the same serotype to $V$. harveyi isolated in our previous work ${ }^{2)}$.

Gross signs and histopathology: At the time of sampling, no macroscopic white spots were observed on the body of affected shrimp. Histopathological examination did not reveal signs of infection with WSSV, Penaeus monodon-type baculovirus (MBV) or Hepatopancreatic parvovirus (HPV) infections. However, the histological

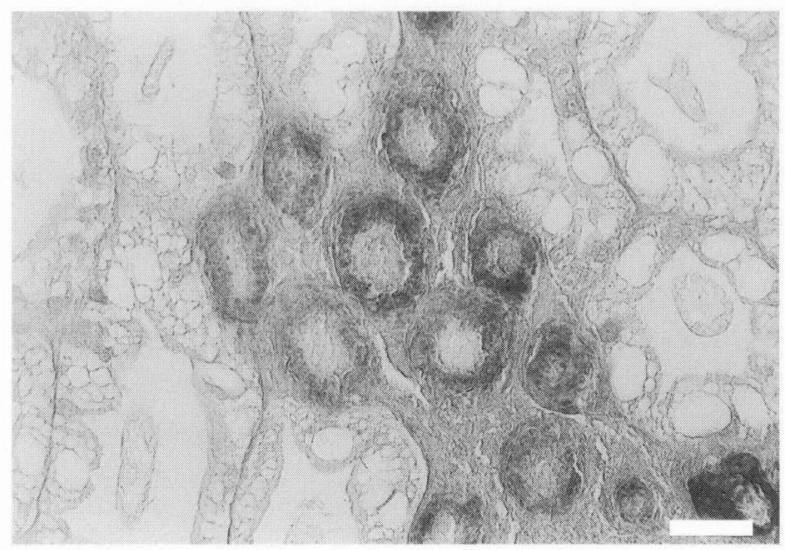

Fig. 1. Histological section of hepatopancreas of infected shrimp from a farm in Bohol showing chronic inflammatory lesions in the form of melanized hemocytic nodules in the intertubular spaces. H \& E stain, bar = $50 \mu \mathrm{m}$.

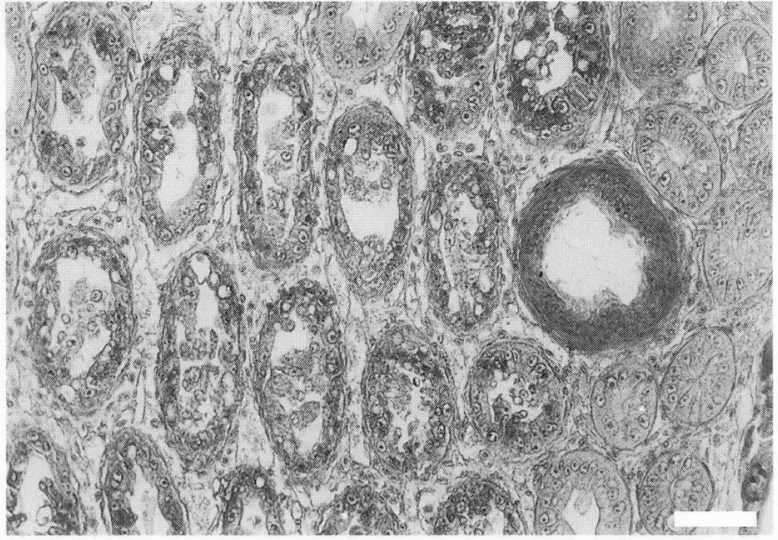

Fig. 2. Histological section of hepatopancreas of infected shrimp from a farm in Mindanao showing chronic inflammatory lesions in the form of melanized hemocytic nodules. $\mathrm{H} \& \mathrm{E}$ stain, $\mathrm{bar}=50 \mu \mathrm{m}$.

sections of hepatopancreas showed clear evidence of inflammatory lesions in the form of hemocytic aggregation, nodule formation and melanization (Figs. 1 and 2).

One-step and nested PCR: Electrophoresis of the PCR products of first step amplification did not reveal the presence of WSSV DNA (982 bp product) in all the samples except 2 pooled samples of the gills and epidermis from Mindanao. However, in the nested PCR, clear amplification (570 bp product) was obtained in all the samples except 1 pooled epidermis sample from Bohol (Fig. 3).

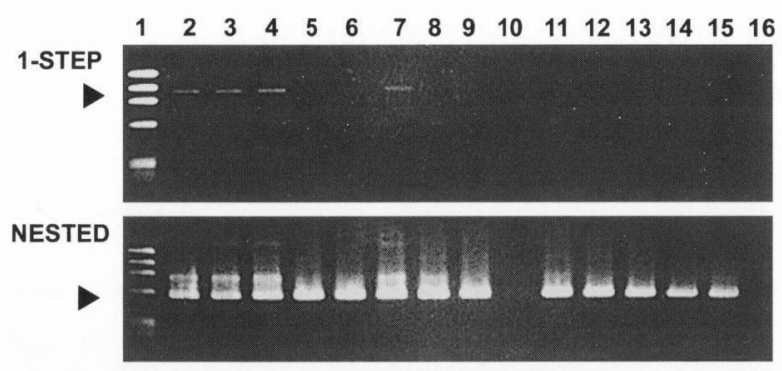

Fig. 3. Agarose gel electrophoresis of PCR amplification products of WSSV. Lanes: (1) $\phi \times 174-\mathrm{Hae}$ III DNA marker; (2-3) positive controls; (4-6) pooled gill samples from Mindanao; (7-9) pooled epidermis samples from Mindanao; (10-12) pooled epidermis samples from Bohol; (13-15) pooled gill samples from Bohol; (16) negative control.

\section{Discussion}

This study confirmed the presence of dual $V$. harveyi and WSSV infection in affected shrimp. There are few reports that correlate bacterial infection with WSSV infection in penaeid shrimp. Vibrio alginolyticus was isolated from the hemolymph of moribund $P$. monodon during the outbreaks of WSSV infection in Taiwan ${ }^{7}$, and various Vibrio species were isolated from $P$. monodon infected 
with WSSV in India ${ }^{8)}$. Vibrio penaeicida was isolated from PAV (=WSS) infected $P$. japonicus in Japan with varying incidences ${ }^{9}$. There have been no detailed analysis on the role of the two pathogens, viral and bacterial, in those mortalities. However, bacteria were usually considered as secondary invaders ${ }^{8)}$.

In the present study, $V$. harveyi was the only bacterial species isolated with bacterial count exceeding $10^{6}$ cfu/hepatopancreas. This bacteriological result is further highlighted by the histopathological changes in hepatopancreas which appear as severe inflammatory lesions ${ }^{10}$. Nested $P C R$ produced amplicons specific for WSSV DNA from most of the shrimp tested. However, the majority of these samples gave negative results during the one-step PCR. These results suggest that the causative agent of the present mortalities was $V$. harveyi. However, as to whether WSSV infection has any effect on $V$. harveyi infection, as a predisposing factor, requires to be elucidated by carefully-planned infection experiment.

\section{Acknowledgements}

This study was partly funded by the Japanese Government Trust Fund to SEAFDEC AQD. We are very grateful to Japan International Cooperation Agency (JICA) for partially funding this research in the form of training grant to the first author during the fiscal year 2000. We thank the shrimp farmers who gave us access to their farms for sampling and to $Y$. Kato, $M$. Paner and K.M. Baguisi for their technical assistance.

\section{References}

1) Lavilla-Pitogo, C. R. and L. D. de la Peña (1998): Fish Pathol., 33, 405-411. 2) de la Peña, LD., C. R. Lavilla-Pitogo and M. G. Paner (2001): Fish Pathol., 36, 133-138. 3) Albaladejo, J. D., L. M. Tapay, V. P. Migo, C. G. Alfafara, J. R. Somga, S. L. Mayo, R. C. Miranda, K. T. Natividad, F. O. Magbanua, T. Itami, M. Matsumura, E. C. B. Nadala Jr. and P. C. Loh (1998): In "Advances in Shrimp Biotechnology" (ed. by T. W. Flegel). BIOTEC, The National Center for Genetic Engineering and Biotechnology, Chiengmai, pp. 251-253. 4) Magbanua, F. O., K.T. Natividad, V. P. Migo, C. G. Alfafara, F. O. de la Peña, R. O. Miranda, J. D. Albaladejo, E. C. B. Nadala Jr., P. C. Loh and L. Mahilum-Tapay (2000): Dis. Aquat. Org., 42: 77-82. 5) Nonaka, L., C.A. Venegas, T. Nishizawa and K. Muroga (1998): Fish Pathol., 33, 115-122. (In Japanese with English abstract) 6) Kimura, T., K. Yamano, H. Nakano, K. Momoyama, M. Hiraoka and K. Inouye (1996): Fish Pathol., 31, 93-98. 7) Lee, K. K., S. R. Yu, F. R. Chen, T. I. Yang, and P.C. Liu (1996): Curr. Microbiol., 32, 229-231. 8) Karunasagar, I., S. K. Otta, I. Karunasagar (1997): Aquaculture, 153, 9-13. 9) Nakano, H., H. Koube, S. Umezawa, K. Momoyama, M. Hiraoka, K. Inouye and N. Oseko (1994): Fish Pathol., 29, 135-139. (In Japanese with English abstract) 10) Lavilla-Pitogo, C. R., E. M. Leaño and M. G. Paner (1998): Aquaculture, 164, 337-349. 